\title{
Description and Evaluation of the Wreckfish (Polyprion Americanus) Fishery under Individual Transferable Quotas
}

\author{
JOHN R. GAUVIN
}

South Atlantic Fishery Management Council

Charleston, South Carolina

JOHN M. WARD

Southeast Regional Office, NMFS

St. Petersburg, Florida

EDWARD E. BURGESS

Southeast Regional Office, NMFS

St. Petersburg, Florida

\begin{abstract}
The individual transferable quota (ITQ) system for wreckfish (Polyprion americanus) in the south Atlantic will be an important test of the practical merits of individual quota management for finfish fisheries in the United States. This paper describes the wreckfish ITQ program in detail and discusses difficulties encountered in its development. Beyond providing information on the practical constraints of setting up ITQs to managers contemplating ITQs for other fisheries, another goal is to evaluate the degree to which the wreckfish ITQ program is accomplishing its resource conservation, economic, and conflict reduction objectives. Analysis of data and experiences over the one and one-half year period during which the wreckfish ITQ has been in place are provided. Linked to the discussion of accomplishing objectives is an evaluation of the degree that consolidation has taken place and the tradeoff between efficiency goals and concerns over monopoly power.
\end{abstract}

Keywords Management, evaluation, individual transferable quotas, overcapitalization, efficiency, conservation.

\section{Introduction}

There are currently at least forty individual quota management systems operating in the world's fisheries (Muse, 1991). The first individual quota systems began in the early 1970's, and several were implemented in the 1980 's, largely as a reaction to the failure of license limitation programs to curb the impetus to increase gross fishing power despite the fact that the number of fishery participants was held in check (Christy, 1973). Individual transferable quota (ITQ) systems are used in two federally managed fisheries in the United States. One is for the mid-Atlantic surf clam and ocean quahog fishery, implemented in 1989, and a second for the south Atlantic wreckfish fishery, implemented in January 1992.

The concept of controlled access has been discussed in the United States for some time. Individual quota systems, where harvest rights are tradable, are seen 
as a potential solution to recurring economic and biological problems resulting from traditional input management (e.g. closed seasons, gear restrictions, and closed areas). Recent case studies of foreign ITQ management have provided guidance to managers on these issues (Muse and Schelle, 1988; Clark et al., 1988; Sissenwine and Mace, 1991). Case studies of domestic ITQ systems are needed, however, to evaluate the performance of ITQ management under the constraints of the Magnuson Fishery Conservation and Management Act (MFCMA) and other appreciable differences between the commercial fishing sector in this country and abroad.

This paper focuses on the economic and stock conservation effects of ITQ management on the wreckfish fishery. A comparison of the stated objectives of the wreckfish ITQ plan to available evidence from the fishery approximately one and one-half years after implementation in January, 1992 is presented.

A controversial issue for the South Atlantic Fishery Management Council during the design phase of the wreckfish system was whether to place caps on share sizes so that business entities would not acquire excessive market power. After analyzing consolidation that has occurred, the tradeoff between consolidation and economic efficiency under ITQs is discussed. In addition to economic efficiency objectives, the ability of an ITQ to reduce conflicts between fishermen and create resource conservation and regulatory compliance incentives is explored in detail. The track record of the wreckfish ITQ in the area of regulatory compliance, changes in the degree to which fishermen lobby managers for increases in total allowable catch (TAC), and signs of economic vesting in the wreckfish ITQ program are each presented as different types of evidence that the wreckfish ITQ has created some conservation incentives.

Initially, the paper describes the fishery and early management measures. Secondly, the development of the ITQ program and associated contentious issues are presented. Council deliberations and industry concerns over initial allocation, sale restrictions, and potential recovery of resource rent are discussed in this section. Third is an evaluation of the available evidence on industry concentration and exvessel prices to determine how well the objectives of the South Atlantic Fisheries Management Council (SAFMC) for economic efficiency and exvessel price stability are being achieved. Available evidence on incentives for resource conservation and conflict reduction are also discussed in the third section. The paper concludes with a summary and discussion of the quality of available evidence as well as some suggestion for future research.

\section{The Wreckfish Fishery and Management Prior to ITQs}

Wreckfish (Polyprion americanus) is a member of the temperate bass family and is closely related to the more widely known striped bass (Morone saxatilis). Wreckfish are found on the Blake Plateau about 120 miles southeast from Savannah, Georgia at depths between 250 and 400 fathoms (500 and 800 meters). Most fishing activity for the traditional demersal species targeted by commercial fishermen in the south Atlantic such as snappers and groupers occurs on reef habitat inside of 100 fathoms (200 meters) depth on the Continental Shelf.

The fishery for wreckfish is fairly new. Wreckfish were first caught in the mid 1980s by swordfish longliners retrieving pieces of parted pelagic longline gear. As one might imagine, the discovery of these 30 pound grouper-like fish was wel- 
comed because many southeastern fisheries are presently either fully exploited or overfished. Later, fishermen targeting wreckfish designed a gear and a fishing technique called "motor fishing" whereby stainless steel cable with heavy lead weights and leaders with baited hooks are fished vertically from multiple hydraulic reels. The vessel is held in place by motoring against the current. Once the idea that the wreckfish could be marketed as grouper became widespread, the fishery expanded rapidly.

The directed fishery began with two vessels landing fewer than 30,000 pounds in 1987. In 1988, there were six boats and landings increased to over 300,000 pounds. By 1989 , over two million pounds of wreckfish were caught by roughly 25 vessels. This increased to four million pounds for calendar year 1990, landed by more than 40 vessels. Given catch per trip averaged around 7,000 pounds and exvessel prices varied between $\$ 0.90$ and $\$ 1.35$ per pound in the early years of the fishery, wreckfish became one of the largest revenue per trip fishing opportunities in the Southeast (SAFMC, 1990b).

Wreckfish are often marketed in the south Atlantic as a substitute for grouper although markets exist for the species outside this country. For instance, in Portugal wreckfish commands the highest per kilo exvessel price of all demersal fish (Estatisticas de Pesca do Portugal, 1991).

The Council attempted to bring the fishery under control in 1990 . In a relatively short period of time, a permit system was established. In addition, a procedure for setting total allowable catch, a control data for establishing eligibility for limited entry, and a spawning closure were developed (SAFMC, 1990a). Other regulations promulgated for the open access phase of the fishery were trip limits, mandatory hailing before off loading, and restricted off loading hours (SAFMC, 1991a). Finally, the use of bottom longlines was prohibited due to evidence of heavy gear loss and habitat damage.

As has been observed in other fisheries under total allowable catch management (Clark, 1990), the pace of wreckfish fishing greatly increased as boats competed for available catch. Competitive fishing under a restrictive TAC is often called "fishing derbies" or "Olympic-style fisheries"' by fishery participants because the drive to get a portion of available quota often means fishermen are lined up at the start of the fishing year. The race for fish led to a two million pound harvest of wreckfish in the first two months of 1990 before the Council's TAC and fishing year regulations could be implemented. After the regulations to specify total allowable catch were in place, the two million pound TAC for fishing year 1990 was met in approximately four months during the post-spawning period. This is a time when wreckfish fishing had usually been very slow and prices low with markets saturated with authentic groupers.

The rapid pace of landings in the south Atlantic wreckfish fishery brought dockside prices to record lows because markets were not available to absorb that quantity of wreckfish in a short period of time (SAFMC, 1991b). Fishing costs were reportedly high because fishermen were in effect forced to fish in bad weather and when fishing was poor. The rapid pace of landings also brought about intense conflicts among fishermen and some dangerous fishing practices as competition ensued on the relatively small fishing grounds (SAFMC, 1991b). These conflicts were exacerbated by the occasional use of bottom longlines despite the prohibition on their use (Miles Mackaness, Johns Island Fisheries, Johns Island, South Carolina; personal communication). 
Although fishermen were advised that if they could not prove they landed wreckfish in 1990 or before, they would not necessarily be eligible for participation in a future controlled access system, boats continued to be rigged and there were roughly 90 vessels permitted for wreckfish in 1991. The Council was concurrently evaluating controlled access options for the burgeoning wreckfish fishery. Wreckfish clearly represented one of the most lucrative fishing opportunities in the Southeast and this was creating large incentives for fishermen to enter the fishery. Annual net returns to owner/operators were conservatively estimated to range from $\$ 35,000$ to $\$ 97,000$, and this estimate assigned all vessel and gear fixed costs to wreckfish fishing despite their use in other fisheries for part of the year (SAFMC, 1990b). These are considerable annual net returns for vessels typically worth approximately $\$ 180,000$ to $\$ 250,000$. Given incentives for entry, over the span of just a few years, it was widely acknowledged that the fishery was already experiencing overcapitalization.

With the two million pounds TAC, the roughly $\$ 3$ million exvessel revenue was not adequate to support approximately 90 full time vessels permitted in 1991 because wreckfish vessels typically require at least $\$ 150,000$ in annual gross revenue to make ends meet (in reality, not all boats actually fished full time). The small and relatively distant fishing grounds also posed problems in terms of conflicts between fishermen on the water as well as detection and compliance problems. The fishery is prosecuted farther offshore than most fisheries within the purview of the SAFMC and resources for at-sea enforcement of regulations are extremely limited in the Southeast.

Wreckfish trips land wreckfish almost exclusively and the only other species caught in significant quantities during wreckfish trips is dolphinfish (Coryphaena hippurus) taken by rod and reel gear. The single species nature of the fishery and the relatively small number of participants (compared to other Southeastern fisheries with as many as 1,500 permitted fishermen), as well as the absence of a recreational component made the fishery appear to be an excellent candidate for an individual transferable quota system.

\section{ITQ Management for Wreckfish}

Most of the problems and objectives deliberated by the SAFMC during the development of the ITQ program addressed economic concerns in the fishery such as a harvest pace that outstripped market forces and increasing capitalization in the fleet. Other objectives were decreasing conflicts among fishermen and creating incentives for compliance with fishery regulations. One unique objective of the plan considers conservation effects from ITQ management. That objective states that the wreckfish ITQ will give fishermen a vested interest in the fishery, thus linking fishermen's long term economic interest with the viability of the fishery. This is supposed to create incentives for conservation and regulatory compliance whereby fishermen can realize long-run benefits from efforts to conserve and manage the resource.

In early 1991, arguments for trying ITQs for wreckfish were steadily gaining force and increased effort was made to have an ITQ program in place for the 1992-1993 fishing year which started in April of 1992. The mechanics of the wreckfish ITQ program that was implemented are not complicated. Shares were 
allocated to historical participants weighted partially on catch history. Shares were issued only to vessel owners, although fish dealers, processors, or anyone who owned a vessel or vessels meeting historical catch requirements was eligible for an initial allocation share. The specific criteria for eligibility was that catches of at least 5,000 pounds of wreckfish in either 1989 or 1990 had to be documented. Applicants were responsible for providing fish house receipts and affidavits from fish houses for their catches. Official landing records were used to verify submitted records.

The initial allocation formula eventually agreed upon struck a balance between those who advocated using only historical catch to divide shares and those seeking an equal division of shares among eligible fishermen. The initial allocation formula divided 50 of the 100 available percentage shares in direct proportion to the applicant's documented catch over the 1987-1990 period. The remaining 50 shares were divided equally among eligible applicants. The total share that an applicant received was a summation of the two sub-allocations of 50 shares.

For the initial allocation, a single business entity could not receive more than 10 of the 100 shares. The rationale for placing limits on share sizes at the outset was to prevent an entity from receiving an initial share which might create an unfair advantage in terms of purchasing shares from other entities. Another reason initial shares were to be capped at 10 percent was that there was some uncertainty over the fairness of the formula to be used for the initial allocation. A predictive model to simulate the outcome of the initial allocation was developed by the SAFMC staff but the accuracy of fishermen's catch estimates used in the model was questionable.

Shares are fully marketable and divisible and can be purchased by anyone. The wording to describe the duration of rights (percentage shares) is that shares are "of indefinite duration". One explicit caveat on the disposition of shares is that the program could be rescinded if the SAFMC determines that it is not meeting its objectives. That is a possibility for any management measure, however, and a plan amendment would be required to modify the wreckfish ITQ, thus requiring adherence to the requirements of the Magnuson Act and other applicable laws. An additional restriction to the program is that the SAFMC states in the plan that it feels shares should be subject to forfeiture if the share owner of his agents are convicted of a gross violation such as non-reporting of catch or using bottom longline gear.

Fishermen's catches are tallied through a catch coupon system. Fishermen are issued coupons each year in 500 and 100 pounds denominations equalling (after rounding) the weight of wreckfish corresponding to the shareholder's percentage share of the annual TAC. Catch coupons have embedded permit digits and coding digits that allow for automated processing with a reader device that debits the appropriate fisherman's ITQ account automatically. The code digits attempt to thwart coupon counterfeiting.

Coupons are separable at the center crease and the portion marked "dealer side" is to be given by the fisherman to the fish dealer when fish are purchased. Coupons must be canceled and submitted to the NMFS on a monthly basis by dealers permitted to purchase wreckfish. The "fishermen's side" of coupons must be canceled by fishermen prior to landing which requires the permitted captain's signature and the data of landing written in ink as well as marking the appropriate 
number circles to indicate the permit number of the vessel. The fisherman is responsible for sending that portion of the coupon to the NMFS after the completion of the trip.

To make it more difficult to exceed individual quotas by not reporting catch, fishermen are responsible for estimating the weight of catch on board prior to landing and canceling the appropriate number of coupons equal to the catch on board. Estimation of catch weight is not considered a difficult task for fishermen due to the nearly uniform individual weights of wreckfish which means that a head count is usually sufficient for estimating catch on board with reasonable accuracy. Enforcement agents inspecting wreckfish landings apply a tolerance factor to the captain's estimate of catch on board, and as long as it is within the tolerance range, there is no penalty for having canceled fewer coupons than was in fact necessary once the catch is unloaded and weighed.

Annual catch coupons are transferable among wreckfish shareholders only. Sale of annual catch coupons when the percentage share is retained by the seller is commonly referred to as "leasing" a share, but involves no lease agreement at all. In actuality, coupons are simply sold and the portion of the coupon designed to record sales of annual catch coupons must be filled out by the seller and buyer. According to the SAFMC plan, allowing sales of catch coupons among shareholders only was done to ensure all participants are subject to a potential share forfeiture for enforcement purposes.

\section{Contentious Issues in the Development of the Wreckfish ITQ}

No restrictions were made on the maximum size of shares after the initial allocation. According to the plan, this was one of the most difficult subjects for the industry advisory panels and the SAFMC during the development phase of the ITQ (SAFMC, 1991b). Debate over the possible negative effects of share consolidation was extensive. Proponents of not restricting share sizes after the initial allocation argued that the core fishermen in the industry would not sell their shares because they had found a valuable business opportunity in wreckfish fishing that could now be protected from unrestrained entry. Another argument was that wreckfish is sold as a grouper substitute and even if only a few parties controlled the wreckfish industry, this would not create market power because wreckfish is a small part of the overall supply of grouper and grouper substitutes.

The notion of how to determine what exactly constitutes a single business entity partially determined why the SAFMC eventually opted not to restrict the size of shares after the initial allocation (SAFMC, 1991b). The SAFMC was apparently aware that businesses could do a number of things to strategically conceal the size of their share after the initial allocation, such as dividing into separate but singly controlled corporations. In the end, the SAFMC resolved to let existing antitrust laws determine whether concentration of shares, to the degree it occurred, was detrimental to the industry or the consumer (SAFMC, 1991b).

Another subject of contention was the characterization of percentage shares that fishermen would receive. Some SAFMC members viewed them as property rights because they were being granted indefinitely. Others had no objection to their characterization as property rights but wanted to put restrictions on their marketability so that fishermen given shares would not be able to immediately sell them and capture some sort of windfall from the initial allocation. In the end, the 
characterization of the rights that prevailed was that shares amounted to a harvest right, or an opportunity to perform the (profitable) service of bringing wreckfish to the American consumer (SAFMC, 1991b). Percentage shares were not considered to be property rights in the legal sense because the SAFMC could modify or rescind the program through the amendment process if it was not accomplishing its objectives.

There was also considerable discussion over whether to create sale restrictions on percentage shares and annual coupons and/or "use it or lose it" clauses. The negative effects of restricting market forces were weighed against potential for reaping windfalls or allowing what was deemed "absentee ownership". Over the course of the development of the plan, it apparently became clear that for the most part, fishery managers lack the ability to determine whether a sale of percentage shares was to a different business entity or not, given the way corporations and other business entities are commonly structured. The same can be said for determining whether a share was really "used"' by its owner, i.e. if catch coupons were sold to a different business entity each year, did that constitute use? The lack of clear resolution when evaluating these issues is apparently why the SAFMC opted not to incorporate sale restrictions into the plan (SAFMC, 1991b).

The SAFMC obviously faced a number of difficult decisions throughout the development of ITQs for wreckfish. Probably the most troublesome was the limitation on collecting from shareholders anything more than the costs of issuing permits despite the fact that shareholders benefit from the ITQ program (SAFMC, 1991b). The Magnuson Act currently does not allow for the recovery of administrative costs beyond those associated with issuing permits. Recovery of fees or any portion of economic rent is presently prohibited, either at the initial allocation (i.e., ITQs must be given out and cannot be auctioned) or at some later date. This apparently posed a philosophical problem for some SAFMC members and hampered the development of the wreckfish ITQ program because some SAFMC members felt the program would make wreckfish fishing more profitable and thought that shareholders should at least pay for the administrative costs of the program (SAFMC, 1991b).

To address this problem, the SAFMC added a provision to the plan to advise ITQ shareholders that the SAFMC believes that some portion of administrative costs in excess of the costs of issuing permits should be collected, if that is allowed under the Magnuson Act in the future. The cost of issuing permits is presently calculated to be approximately $\$ 53.00$ per year for the wreckfish ITQ program. According to the SAFMC's provision, additional fees to offset NMFS costs of tracking and monitoring ITQs will be collected if and when that becomes legal under the Magnuson Act.

According to the plan, the rationale for moving ahead despite some very fundamental objections and disagreement was that the SAFMC was already spending a great deal of fiscal resources devising greater and greater input control measures to slow the fishery down under open access. The need for involvement and the cost of managing the wreckfish fishery under ITQ was expected to be lower with ITQs than under open access, given escalating open access problems associated with the fishing derby that had evolved.

The SAFMC managed to put the program together in slightly more than a year, a relatively short period of time for the plan amendment process involving a completely new management approach. One explanation for this is that wreckfish 
is a single-species fishery with a relatively small number of fishermen and fish dealers. On the other hand, anyone who has followed the regional council management process will be cognizant that even seemingly rudimentary management plans affecting a relatively small number of fishermen are often difficult to put in place if there is little support for the measures being proposed.

The question has arisen as to whether wreckfish fishermen were predisposed to ITQ management. The public hearing record reflects that very few fishermen were in favor of ITQ management for wreckfish when it was first suggested (SAFMC, 1991b). Yet apparently as the terms and concepts became familiar and as fishermen became aware that they would have substantial input into shaping the program, support for ITQ increased and eventually was widespread. Disagreement among fishermen in the latter stages of the plan development focussed not on whether the fishery should have ITQs but how the initial allocation formula should be structured. Newer fishermen favored an equal distribution of shares while established fishermen wanted shares to be divided based on historical catch alone. The acceptability of allocating half of the available shares equally and half based on historical catch apparently struck a compromise between these two positions (SAFMC, 1991b).

Perhaps this was an acceptable middle ground because the fishery was relatively new and differences in initial allocation would not be that great simply because catch history was brief. As has been suggested by Libecap (1989), the willingness of fishermen to accept individual quota regimes may be higher in a new fishery because catch allocations will not differ greatly from what fishermen are currently catching. Libecap points out that firms that are successful under open access will likely oppose ITQs unless the initial allocation scheme ensures recognition of their historical position in the fishery.

\section{The Wreckfish ITQ Program After Implementation}

\section{Overcapitalization and Efficiency Objectives}

Most fishery economists agree that the primary use of ITQs is to address overcapitalization that results in the inherent market failure of open access. Overcapitalization occurs in most open access fisheries worldwide and it is sometimes aggravated by total quota management under open access or license limitation schemes, due to incentives for competitive fishing under those management regimes.

Economists theorize that if markets are reasonably unrestricted and information flows freely between potential buyers, harvest rights will flow to buyers with the highest-valued use of the resource. Thus fishing firms that are more profitable because they have lower per-unit fishing costs, or firms that are able to get higher per-unit prices because of better handling of product or other factors, will have incentives to bid fishing rights away from less profitable firms. This should make the fishing industry more efficient in terms of the operations of those who remain in the fishery and the total amount of harvest capital remaining in the fishery. The SAFMC's objective to address overcapitalization and increase efficiency through the use of ITQs is clearly based on this reasoning (SAFMC, 1991b).

Since ITQs were implemented for wreckfish, the number of fishing firms has decreased. After a year and a half, 31 share holders remained in the fishery from 
49 who were given initial allocations in February 1992 (Table 1), with 23 shareholders selling their shares and five new shareholders entering the fishery. Thus far, there are 22 vessels permitted for the 1993-1994 fishing year although this number is expected to increase as more shareholders renew their permits before the fall fishing period when fishing is normally better (Table 2). There were a total of 40 vessel permits issued for the 1992-1993 fishing year, down from 91 in 19911992, the last year of open access for wreckfish. Even under ITQ management, not every vessel permitted to fish for wreckfish must actually be used in a given year (Table 2). Shareholders may permit their vessels and later decide to sell catch coupons. Some shareholders even have joint harvesting arrangements with other shareholders, and shareholders get permits for extra vessels in case one vessel breaks down.

Given the large drop in the number of shareholders and vessels active in the fishery, one is inclined to conclude that overcapitalization has been reduced by the tradable harvest rights scheme. An analysis based on informally collected cost and earnings data in 1990 suggested that if the number of fishing vessels were determined by rational market forces, the economics of the fishery would support roughly 20 vessels given the cost structure of fishing vessels and future TACs projected at the status quo (two million pounds), (SAFMC, 1990a). In terms of the number of vessels being employed for wreckfish since ITQs, it appears that capitalization is already moving close to that level.

It has been widely touted that ITQs allow fishermen to make efficient adjustments to lower fishing costs. At the same time, reductions in overcapitalization are expected to reduce any inefficiencies from crowding. In reality, a whole set of factors can determine per trip and annual fishing costs for hook and line fishing such as sea conditions, magnitude of currents, and changes in fish abundance.

One piece of available evidence that may indicate efficiency gains is that fishermen have not applied as much effort during the early months of the fishing year as they did before ITQ management. The months of April, May, and June are generally thought to be less productive because they are the post-spawning period when wreckfish are more dispersed than when aggregated for pre-spawning and spawning (SAFMC, 1990a). The number of trips made during the April-June portion of the year has decreased greatly under ITQ fishing (Figure 1). If fishermen are not effectively forced by open access to fish as much during those months, then some efficiency gains may well have occurred under ITQs.

Table 1

Share Ownership

\begin{tabular}{lcrr}
\hline & Start Date & & \\
& $4 / 16 / 92$ & \multicolumn{1}{c}{$8 / 15 / 92$} & \multicolumn{1}{c}{$6 / 17 / 93$} \\
\hline Number of Shareholders & 49 & \multicolumn{1}{c}{37} & \multicolumn{1}{c}{31} \\
Average Shares Owned & 2.041 & 2.703 & 3.226 \\
Shares Held by Largest 5 & 23.805 & 39.482 & 46.131 \\
Average Held by Largest 5 & 4.761 & 7.896 & 9.226 \\
Shares Held by Largest 10 & 39.931 & 58.823 & 69.442 \\
Shares Held by Smallest 5 & 5.454 & 5.395 & 3.369 \\
Shares Held by Smallest 10 & 11.165 & 11.326 & 9.390 \\
\hline
\end{tabular}

Source: Southeast Region, National Marine Fisheries Service 
Table 2

Wreckfish Vessel Permits as of 6/17/93

\begin{tabular}{lccc}
\hline & $1991-92$ & $1992-93$ & $1993-94$ \\
\hline Number of vessels with wreckfish permits & 91 & 40 & 22 \\
Number of vessels reporting wreckfish catch & 44 & 22 & 14 \\
\hline
\end{tabular}

Source: Southeast Region, National Marine Fisheries Service

There has been considerable debate over the potential reason why wreckfish fishermen produced only 1.3 million pounds of the two million pound TAC in the first year of ITQ management, when TACs prior to ITQs had been met (Figure 2). Some saw this as an indication that wreckfish were becoming less abundant. Yet average catch per unit of effort throughout the last fishing year was not below the 1989 to 1991 average (SAFMC, 1993). In addition, most shareholders with large shares caught all of the catch their share translated into and caught the bulk of the annual rights they purchased from shareholders who sold their shares or their catch coupons (SAFMC, 1993). What occurred in the 1992-1993 season may well have been driven more by the process of adjustment during a period of active share trading than any other factor.

An interesting aside is that there is evidence that some shareholders may have had a less than perfect understanding of the mechanics of the system because some did not sell their coupons with the apparent belief that accumulated coupons from past fishing years could be used in later fishing years (SAFMC, 1993). It has

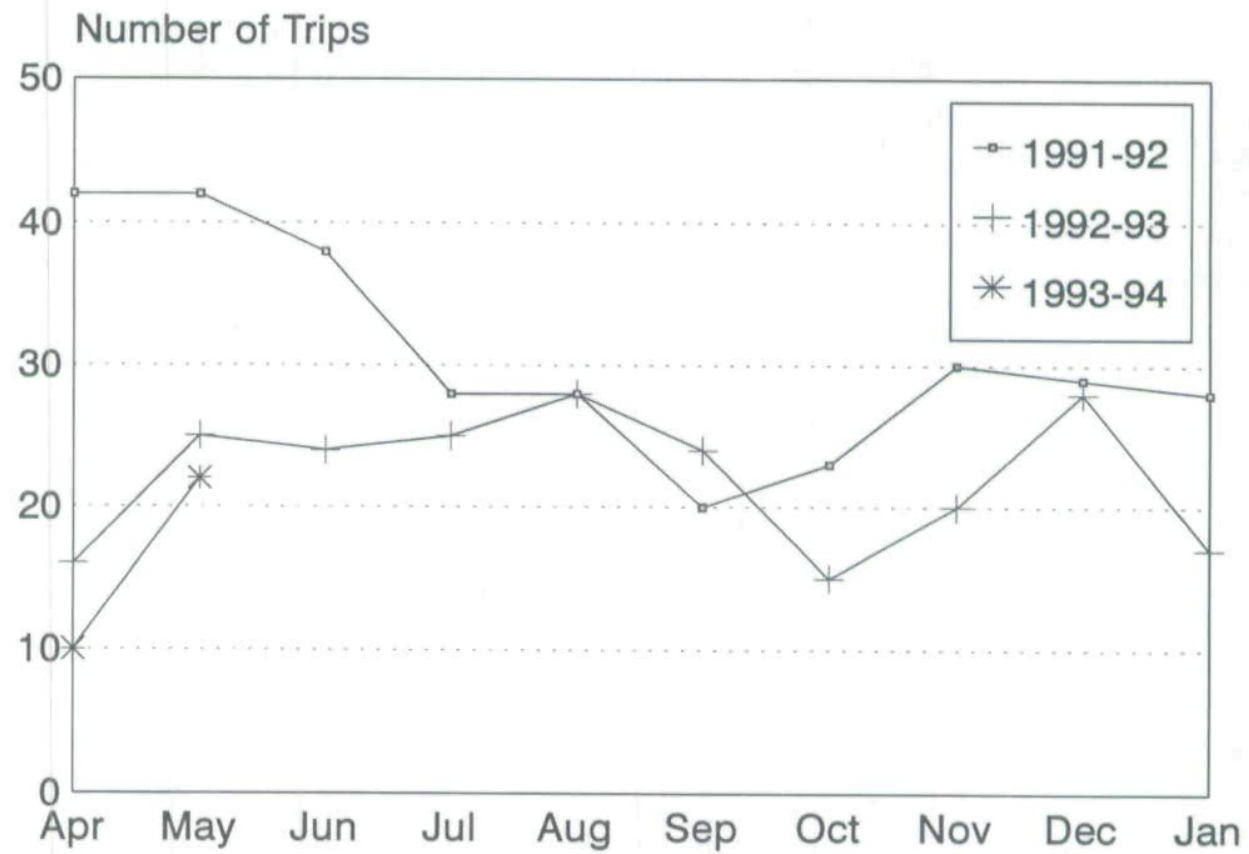

Source: Southeast Region, National Marine Fisheries Service

Figure 1. Wreckfish Trips 


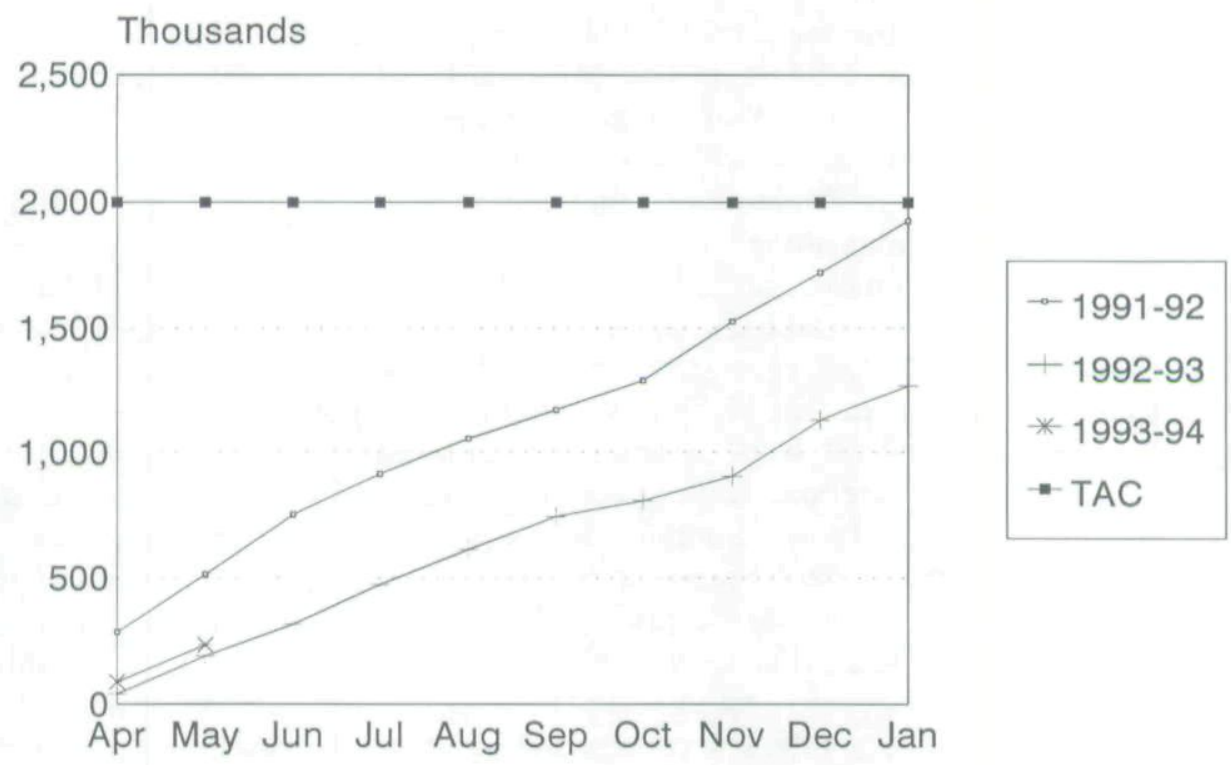

Source: Southeast Region, National Marine Fisheries Service

Figure 2. Accumulated Wreckfish Catch (Whole weight)

also been suggested that shareholders with small shares who are not principally wreckfish fishermen had high opportunity costs last year because of good snapper and grouper fishing and an above average crop of white shrimp, the two fisheries most wreckfish fishermen switch to during the spawning closure for wreckfish (SAFMC, 1993). These fishermen may have decided to pursue more profitable opportunities in other fisheries and could not sell their wreckfish coupons because markets for coupons were not working well due to inexperience. Wreckfish fishermen may also have preferred to establish catch histories on other south Atlantic fisheries in case ITQs are developed for those fisheries. Not catching the entire TAC because some fishermen preferred to establish catch histories or because opportunities in other fisheries were comparatively better last year suggests that ITQs may have allowed very rational economic behavior to occur after all.

\section{The Question of Consolidation}

Although decreasing overcapitalization is an explicit objective of the plan, as rationalization occurs, there could potentially be public outcry that the fishery has been "monopolized" by firms that remain in the fishery or that firms in the fishery now have an inordinate amount of control over prices. The public's concern over consolidation is shared by many managers because it can be used to cast the ITQ system in an unfavorable light. It is important to examine the consolidation that has occurred in the wreckfish ITQ systematically to evaluate whether monopoly or market power is in the hands of the reduced number of shareholders, as some SAFMC members apparently feared (SAFMC, 1991b).

Summary statistics to describe the degree of consolidation in the wreckfish industry can invoke concern among fishermen and observers of the process. For 
instance, the mean share size currently held by the largest five shareholders in the fishery is $9.2 \%$, up from $4.8 \%$ at the time of the initial allocation (Table 1). At face value, this increase appears great but if economic efficiency for the fishery means that approximately 20 vessels will be operating, consolidation has to occur. A systematic approach to evaluating consolidation is beneficial so that opinions are not based on perceptions alone.

To most participants in the fishery, it is not surprising that consolidation occurred rapidly at the outset because the formula for the initial allocation divided shares such that highliners received less than they were catching prior to ITQ management. This meant that highliners would have to purchase shares or coupons to remain at past catch levels and it was apparently widely held that purchasing shares was preferable to purchasing coupons (Miles Mackaness, Johns Island Fisheries, Johns Island, South Carolina; personal communication).

Economists view monopolies and cartels as structures that afford the ability to produce less than what would be produced in a competitive market, causing market prices to be higher than they would be otherwise. This makes monopoly and cartels inherently more profitable than competitive market structures. $\mathrm{Al}-$ though economic theory offers a concise definition of the difference between monopoly and perfect competition, the underlying problem when attempting to make determinations about potential monopoly power is that firm-specific marginal cost and revenue functions are almost never available.

Information on the market share of firms which could also provide some relevant information about how competitive markets operate is equally difficult to obtain in most cases. The wreckfish ITQ program, however, wherein percentage shares are known and available to the public by reporting provisions specified in the program, affords a privileged opportunity to evaluate market power.

To evaluate the current structure of the wreckfish industry, standard economic diagnostics such as Lorenze curves and Gini coefficients were examined to select an unbiased diagnostic to characterize consolidation that has occurred (Scherer, 1970). The basic problem with concentration tables, graphics such as Lorenze curves, and diagnostic coefficients to interpret those graphics is that those measures are not particularly well-suited to making determinations when there are a large number of small firms or when there are a relatively small number of firms with roughly equal share sizes (Scherer, 1970). For this reason, the Herfindahl index was selected because it provides an unbiased assessment of concentration changes over time for industries made up of a relatively small number of firms with small nominal difference in market share.

The Herfindahl index is specified as:

$$
\mathrm{H}=\sum_{\mathrm{i}=1}^{\mathrm{N}} \mathrm{S}^{2}
$$

where $S_{i}$ is the market share of the $i^{\prime}$ th firm. The index squares the percentage shares of each firm and then sums the squares. The index thus varies from close to zero for perfect competition to one for a perfect monopoly (Scherer, 1970).

Herfindahl indices for wreckfish shares at three different points in time were calculated to characterize changes in consolidation. Points in time considered were: at the time of the initial allocation in January of 1992, in August 1992, and 
in June 1993. The significance of the two points in time following the initial allocation is that they follow periods of heavy share trading. The Herfindahl index was 0.027 when shares were first allocated, 0.048 in August of 1992, and 0.064 in June of 1993. The overall change from the initial allocation to June 1993 has been an increase of 0.037 which means the index has increased more than two fold.

Using the index as a basic guideline, one can readily see that consolidation has occurred according to the index, but the index value still remains close to zero. For example, assuming all firms were of equal size, a Herfindahl index of 0.064 implies that there would be 15.6 firms of equal size in the fishery. An industry with approximately 16 firms of equal market share size would probably not seem inherently concentrated to most observers, although information about how prices are determined and other aspects of how markets work would be needed to make determinations about the relative degree of consolidation in such an industry.

Thus far, the SAFMC's decision to allow the market to work without impediments such as caps on share holdings after the initial allocation appears to be reasonable. The tradeoff, however, between the objective of reducing overcapitalization and avoiding excessive concentration depends mostly on the nature of the fishery in question and regional public policy objectives for the fishing industry. A relevant question is whether share size alone is the most important consideration or is price-determining power the key concern? As was mentioned, wreckfish is primarily sold as a substitute for grouper, and the annual production of grouper and other grouper substitutes in the Southeast is nearly ten times that of wreckfish (United States Department of Commerce, 1992). Thus from the perspective of price setting power, if a single business entity controlled wreckfish, any ability to set prices would likely be limited by supply and demand trends for the much greater production of groupers. In the long run, some reasonable guidelines on the issue of share concentration under ITQ management will be valuable to achieving reductions in overcapitalization while allaying public concern.

\section{Changes in Exvessel Prices Under ITQs}

Another objective of the plan was to provide stable exvessel prices while allowing the best use of the resource. The wreckfish ITQ is designed to be a mechanism to allow the pace of landings to better match market forces. Empirical research to establish the determinants of wreckfish prices and quantify the substitutability of wreckfish for grouper would require current data on imports of grouper and grouper substitutes during the period in question which is presently not available. Lacking that, other types of qualitative evidence can be evaluated.

Prior to ITQs, fishermen engaged in a derby fishery with investment in harvest capacity increasing from two to ninety vessels over a five year period and the length of the fishing season declining to four months in 1990 . The contraction of the fishing season resulted in supply gluts that reduced market prices and directed product into less than optimal market channels (Micah LaRoche, Cherry Point Seafood, Rockville, SC; personal communication). By creating harvest rights through the ITQ, fishermen no longer have to land fish to own them, resulting in the lengthening of the fishing season. With the ITQ, exvessel prices have not been depressed by market supply gluts nor have wreckfish been directed into lower valued secondary markets (Micah LaRoche, Cherry Point Seafood, Rockville, 
SC; personal communication). Lower value markets would be markets for frozen wreckfish or discount fish markets such as supermarkets.

According to reported price data, exvessel prices have thus far behaved as expected. Prior to the ITQ management program, average monthly prices varied from $\$ 0.90$ to $\$ 1.55$ per pound dressed weight (SAFMC, 1991b). Since the implementation of the ITQ program, prices have increased and variation around the market price has declined; fluctuating slightly around $\$ 1.85$ per pound dressed weight (Figure 3). Increases in exvessel prices that have occurred for wreckfish have been accompanied by a decrease in the number of fishery participants as evidenced by the increasing Herfindahl index. In a common property fishery, participation would have increased substantially with an increase in price, all other things remaining constant (Anderson, 1990).

\section{Incentives For Conservation and Regulatory Compliance Under ITQ Management}

One of the more difficult determinations to make in evaluating the wreckfish ITQ program is whether conservation incentives have been created. Some theorists see conservation incentives through ITQs because if fishermen have a vested interest in the long run viability of the resource, conservation is essentially in their long run economic interest (Dr. Lee Anderson, University of Delaware, College of Marine Science, personal communication). Certainly, the effective discount rates of fishermen would influence the degree that conservation incentives are created from having a vested interest in the fishery. After considering this issue in detail, the SAFMC was sufficiently persuaded that incentives for conservation and regulatory compliance would be created that it made conservation and regulatory compliance objectives part of the objectives for the wreckfish ITQ.

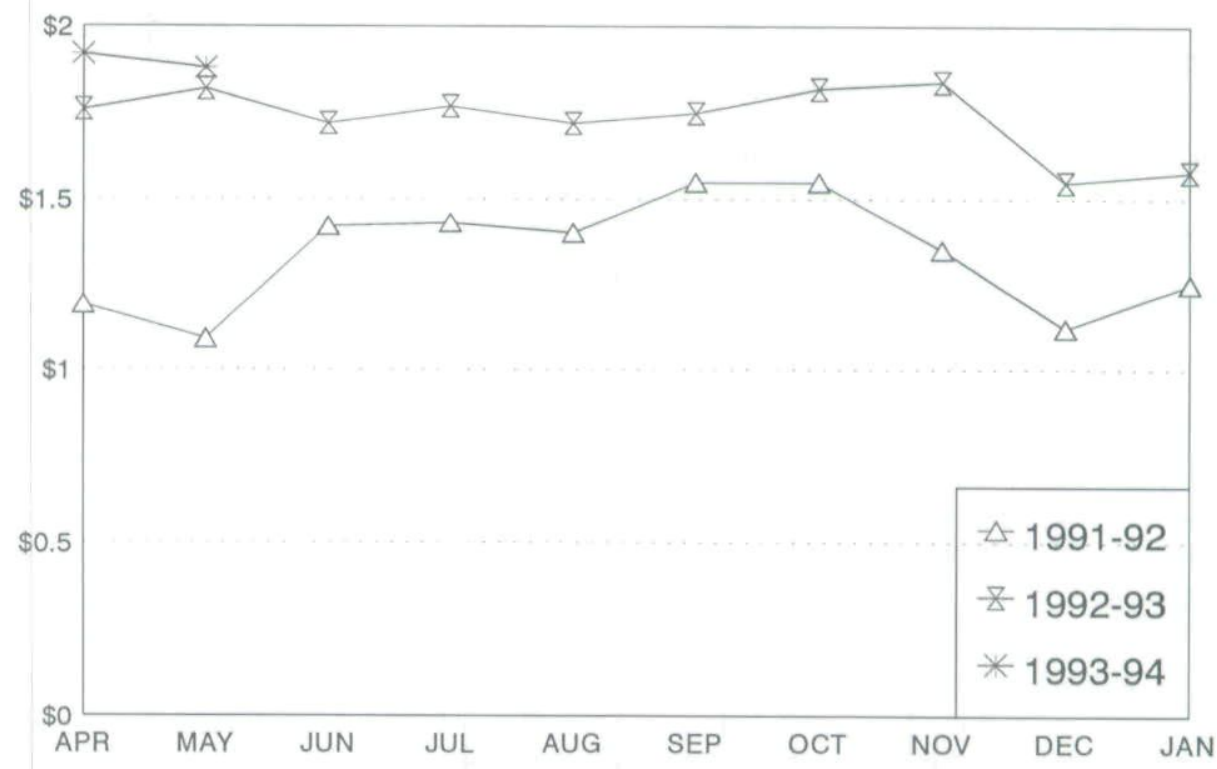

Source: Southeast Region, National Marine Fisheries Service

Figure 3. Wreckfish prices per pound (dressed weight) 
Although the ITQ has only been in place for a relatively short period of time, there is certainly anecdotal evidence that conservation motivations have increased. Before ITQs, some wreckfish fishermen repeatedly requested the SAFMC to set much higher TACs for the fishery, such as six or eight million pounds (SAFMC 1990a, SAFMC 1991b). These fishermen consistently argued that there is no good biological evidence that wreckfish are being overfished or that the stock could not support higher rates of removal.

At the public hearings for annual TAC setting since ITQ management has been in place (February 1992 and January 1993), there was a conspicuous absence of any lobbying of the SAFMC for larger TACs. Again, one cannot say for sure whether this stems from conservation incentives, but given the persistence of fishermen who requested larger quotas prior to ITQs, it does appear that this could be a sign of change in perspective on the part of fishermen.

A measure of conservation incentives from an economic perspective can be derived by examining markets for percentage shares and catch coupons in the fishery. In theory, if the ITQ ties fishermen's economic futures to a sustainable fishery, then it will be in their best interest to promote conservation of the resource. Differences between share prices and the price of annual wreckfish catch coupons can be used to provide insights into fishermen's expectations for the fishery.

Fishermen are responsible for reporting coupon and share sales prices under the wreckfish ITQ system. Reports thus far indicate that coupons are selling on average for $\$ 0.30$ on a per pound of catch basis while shares (or permanent harvest rights) are selling for approximately $\$ 0.50$ per pound. One can argue that there is incomplete understanding about the worth of shares and coupons since fishermen are in a position to trade harvest rights for the first time. There may also be some incentives for under reporting share sales prices to avoid capital gains taxes and markets for coupons may not have functioned as well as expected during the first year of the ITQ. These factors argue for viewing the information presented here with appropriate caution.

The above caveats acknowledged, coupon prices are the best available evidence of the rent generated by the wreckfish fishery for a pound of fish that is still in the sea. By way of the workings of the market for coupons, a price is derived such that the seller feels he can make somewhat less than $\$ 0.30$ per pound by fishing or he would not be inclined to sell the coupons for that price, selecting instead to use the coupons by fishing for the wreckfish. The buyer believes he can make more than $\$ 0.30$ per pound by catching the amount of wreckfish designated by the coupons or he would be indifferent to purchasing coupons. Thus the price of $\$ 0.30$ per pound is a reflection of the profit on a pound of wreckfish generated by the least efficient fisherman in the industry at this point in time.

If one considers that shares were granted for an indefinite duration, then each pound of wreckfish that a share translates into on an annual basis should reflect a marginal value of $\$ 0.30$ per pound. Thus if fishermen embrace the future perfectly in the wreckfish program, they would be expected to view their shares as an asset worth the equivalent of an infinite stream of discounted profits from that asset. According to this way of looking at the difference between coupon and share prices, fishermen are in effect embracing the future in the ITQ program because the price for shares $(\$ 0.50$ per pound) is greater than the per pound price for coupons. The degree of the difference tells something about fishermen's ex- 
pectations for the ITQ or the wreckfish stock or both, and the effective discount rate one assigns to fishermen has bearing on how one evaluates the difference between share and coupon prices.

An infinitely high discount rate is often used to characterize a common property fishery. A $\$ 0.50$ per pound share price is the present value of a $\$ 0.30$ per pound coupon price discounted over an infinite time horizon at a high discount rate $(150 \%)$. The discount rate found for wreckfish is substantially less than infinity, but does indicate that the hoped for market incentives that would induce stock conservation had less of an impact than originally expected. The high discount rate could reflect the concerns of fishermen that the ITQ program will be rescinded in the near future, their belief that the stock may be unable to support the fishery into the future, or inexperience in trading coupon and shares in the ITQ marketplace. Regardless of the reasons, fishermen are showing at least some regard for the future through their ITQ share and coupon purchasing decisions, and although the market impact on stock conservation may be less than expected, it is considerably more effective than that which occurs under open access.

Another indicator of conservation motivations for the wreckfish fishery is that compliance with the prohibition on the use of bottom longlines is thought to be improved since controlled access has been implemented. When the fishery was managed by open access, fishermen had large incentives to use bottom longlines despite the fact that the gear is thought to destroy the fishing grounds because at depths and bottom contours where wreckfish are caught, the longline mainline is easily parted (SAFMC, 1991a). Fishermen began using longlines because fish could be caught much faster than with vertical hook and line gear and use of longlines paid for itself even if the boat ended up losing all or most of its mainline cable in a short period of time. Fishermen openly admitted at public hearings that they would not have used longline gear if no one else in the fishery was using it because the large pieces of parted cable were destroying some of the fishing grounds (SAFMC, 1991a). The cable that was used for bottom longlines is capable of doing significant damage to the coral and ledge habitats of the Blake Plateau. Yet fishermen apparently claimed they had to use bottom longlines in order to catch as much as they could before the TAC was filled (SAFMC, 1991a). At sea enforcement of the fishing grounds was minimal and reports of the continued use of longline gear following its prohibition were widespread.

Ending the fishing derby probably defeated most incentives for use of bottom longlines in the fishery. Yet there will always be some incentives for using very effective gear if using the gear makes fishing more profitable. This is where incentives from aligning the long run interests of fishermen more closely with the interests of the resource may play a role. In this particular case, conservation incentives have been observed in the form of vigilance on the part of fishermen in providing information to enforcement agents when a fisherman is suspected of using bottom longline gear. Coast Guard and NMFS law enforcement officers have repeatedly commented on the increased willingness of fishermen to cooperate and provide information to enforcement officials under the ITQ system (Mr. Paul Raymond, Special Agent, NMFS, Southeast Region Law Enforcement Office; personal communication).

The track record of ITQ management when it comes to compliance with fishery regulations that prohibit exceeding total quota has been observed in some 
fisheries under ITQs. The prevalence of quota "busting", in the form of exceeding individual quotas, not reporting discarded bycatch, or highgrading of quota fish has been pointed out (Copes, 1986). The original theorists of ITQs probably did not envision the degree to which incentives to cheat, discard, or highgrade catch might influence the behavior of fishermen. Quota busting defeats the resource conservation effects of the TAC by allowing fishing mortality to exceed what biological assessments have identified as safe levels of fishing for the stock. Evidence of quota busting would suggest that fishermen are not embracing the conservation incentives the SAFMC feels the ITQ program will create.

Thus far, enforcement officials report very good compliance by fishermen with requirements to fill out catch coupons to report catch prior to landing. The intent of issuing small denominations of coupons ( 500 pounds is the largest denomination) was to require a significant amount of signing and marking of coupons so fishermen would not be able to wait until an enforcement officer approached their vessels before beginning to cancel coupons. It takes approximately three to five minutes to cancel coupons for a 10,000 pound trip of wreckfish. It is a violation for a fisherman to pre-sign or mark coupons in order to speed up the time it takes to cancel coupons because only the date would then have to be written on coupons before they are canceled. Thus far, there has only been one case made for alleged quota busting since the start of ITQ management.

At this point, there is no evidence that quota busting is widespread in the wreckfish fishery. If regulatory compliance with the rules against quota busting for the wreckfish ITQ is occurring, it may be partially driven by conservation incentives. It may also be occurring for other reasons. One such reason may be the high penalty for violation. Another may be the low price of catch coupons and percentage shares at this point which probably allows fishermen to acquire additional catch rights at a low price, thus making quota busting somewhat less attractive.

\section{Conflict Resolution}

Decreasing conflicts among fishermen is also an important objective of the ITQ program. The SAFMC heard repeated and extensive testimony from fishermen on the nature and extent of conflicts in the fishing grounds under open access (SAFMC, 1991b). As was mentioned above, the pressures of the fishing derby and the relatively small fishing grounds lead to near collisions between vessels as well as gear conflict between fishermen using vertical hook and line gear and bottom longline gear as vertical line fishermen became entangled in parted longline cable.

The prohibition on bottom longlines probably resolved much of the most serious conflicts among fishermen. There is evidence, however, that illegal bottom longlining continued after the prohibition, and many fishermen now attribute the share forfeiture penalty of the ITQ with the final elimination of the practice of bottom longlining (Miles Mackaness, Johns Island Fisheries, Johns Island, South Carolina; personal communication). Beyond the high penalty for bottom longlining under the ITQ, the removal of the impetus to catch fish as fast as possible probably decreased incentives to use bottom longlines. At present, public hearing testimony and advisory panels have suggested that conflicts among fishermen have been reduce significantly since the advent of ITQ management. 


\section{Summary and Conclusions}

This paper has described the wreckfish fishery and its management under open access and since the implementation of ITQs in April 1992. Detailed attention has been given to the SAFMC's reasoning for shaping the ITQ program in the manner it did, and the concerns of SAFMC members, and fishery participants regarding such things as characterization of rights, initial allocation formula, and consolidation concerns. In addition, some of the concern during the development of the wreckfish ITQ over the present inability of management to recover administrative costs or rents is described. Overall, the paper examines the design of the wreckfish ITQ and how the design may be affecting the degree to which economic and conservation objectives of the program are being realized.

Preliminary analysis suggests that most of the plan objectives are being realized to some degree. The number of shareholders has decreased and there is at least preliminary evidence that harvest rights are flowing to fishing firms with the highest valued use of the resource. There is some evidence that the total amount of capital and fishing effort is decreasing and more efficient use of the remaining capital in the fishery is occurring. Prices to fishermen have increased significantly over pre-ITQ levels, although econometric work to establish that ITQ management is responsible for this increase has not been undertaken.

It must be remembered that determinations about efficiency changes under ITQs are difficult to make given available data. Efficiency comparisons prior to and during ITQ management are, of course, also clouded by past management constraints on efficiency. For equity reasons prior to ITQs, trip limits of 10,000 pounds were used to spread the catch over the season and among the fishermen more evenly. Most boats in the fishery have a hold capacity of well over 10,000 pounds, and these vessels were landing trips in excess of 10,000 pounds prior to trip limits. Under ITQs, trip limits were removed and this alone may have allowed for more efficient use of vessels in the fishery.

In a simplistic sense, if there are now far fewer vessels producing the same quantity of wreckfish, one might assume fishing is more efficient. This would not be true, however, if wreckfish had become relatively more abundant from year to year. Another consideration is that, in reality, wreckfish fishermen have not caught the same amount each year and this complicates analysis of factors to gauge efficiency changes. Even if we had cost and earnings data to compare fishing costs before and after ITQs, external factors may be responsible for changes in costs and these factors are not directly related to ITQ management.

While persuasive, attributing the increase and stability of exvessel prices solely to the ITQ management system would require extensive empirical evidence. A dedicated study of the determinants of wreckfish prices should be undertaken when import data become available so that definitive conclusions can be made about the role of the ITQ in price determination.

Analysis of share consolidation reveals that shares are somewhat more concentrated than before trading began but markets are still competitive. The degree to which the SAFMC has accomplished its objective to create conservation incentives by vesting fishermen in the long run interest of the fishery is more difficult to analyze. Observations on regulatory compliance and decreases in industry lobbying for higher TACs suggest that resource conservation incentives have been created. Diagnostics performed reveal that fishermen are in fact em- 
bracing the long run because markets for shares reflect that fishermen are expecting some stream of future capitalized net benefits from the fishery. Future analyses may discover that traded share prices increase as more information about the wreckfish stock becomes available and fishermen gain more experience with valuing an asset such as ITQ rights. If this occurs, then more evidence that conservation incentives have been created will be available.

Another area that merits study as data become available is the effects of the wreckfish ITQ on other fisheries in the Southeast. Rationalization of the wreckfish fishery to date and future rationalization will likely shift effort from wreckfish to stressed fish stocks managed under the SAFMC's fishery management plan for snapper grouper species such as deep water groupers and tilefish as well as inshore snapper and grouper species. None of these fisheries is presently managed under TACs because of inherent difficulties of putting multiple species fisheries into quota management. The input control measures presently in place for snapper and grouper species may not be adequate to protect these stocks because the potential influx of effort from wreckfish vessels could outstrip whatever protection input controls offer those stocks. Analysis of the wreckfish ITQ and its effects on adjacent fisheries would provide insights into the question of whether it is prudent to establish ITQ programs piecemeal rather than using an integrated approach.

\section{References}

Adams, C. M. and F. J. Lawlor. 1990. An overview of the importation of Latin American seafood products into the United States with an emphasis on selected finfish species. Staff Paper \#395. Food and Resource Economics Department, University of Florida at Gainesville.

Biro, E. 1992. Wide support for the wreckfish plan. National Fisherman 73:3 pp 16-19.

Christy, F. T. Jr. 1973. Fisherman quotas: a tentative suggestion for domestic management. Law of the Institute Occasion Paper \#19. Honolulu, Hawaii.

Clark, I. N. 1990. Mathematical Bioeconomics. John Wiley, New York.

Clark, I. N., P. J. Major, and N. Mollet. 1988. Development and implementation of New Zealand's ITQ management system. Mar. Resour. Econ. 5:325-349.

Copes, P. 1986. A critical review of the individual quota as a device in fisheries management. Land Economics 62(3):278-291.

Estatisticas da Pesca do Portugal. Lisboa, Portugal. 1970-. Instituto Nacional de Estatistica.

Gordon, H. S. 1954. The economic theory of a common property resource: the fishery. Journal of Political Economy 62:124-142.

Libecap, G. D. 1989. Contracting For Property Rights. Cambridge University Press, Cambridge.

Muse, B. 1991. Survey of individual quota programs. Alaska Commercial Entry Commission, Juneau, Alaska.

Muse, B. and K. Schelle, 1989. Individual fisherman's quotas: a preliminary review of some recent programs. Alaska Commercial Fisheries Entry Commission, Juneau, Alaska.

Robinson, William L. 1985. Effort management in Australian fisheries: a presentation to the Gulf of Mexico Fishery Management Council. July 10, 34p.

Scherer, F. M. 1970. Industrial Market Structures and Economic Performance. Rand McNally Academic Publishers, Chicago.

SAFMC. 1990a. South Atlantic Fishery Management Council. Amendment 3 (Wreckfish), 
Regulatory Impact Review, Initial Regulatory Flexibility Analysis and Environmental Assessment for the Fishery Management Plan for the Snapper Grouper Fishery of the South Atlantic Region.

SAFMC. 1990b. Snapper grouper assessment group wreckfish report, May 23-24, 1990. Available from the South Atlantic Fishery Management Council, 1 Southpark Circle, suite 306, Charleston, South Carolina, 29407.

SAFMC. 1991a. South Atlantic Fishery Management Council. Amendment 4, Regulatory Impact Review, Initial Regulatory Flexibility Analysis and Environmental Assessment for the Fishery Management Plan for the Snapper Grouper Fishery of the South Atlantic Region.

SAFMC. 1991b. South Atlantic Fishery Management Council. Amendment 5 (Wreckfish), Regulatory Impact Review, Initial Regulatory Flexibility Analysis and Environmental Assessment for the Fishery Management Plan for the Snapper Grouper Fishery of the South Atlantic Region.

SAFMC. 1993. Snapper grouper assessment group wreckfish report, January 11-12, 1993. Available from the South Atlantic Fishery Management Council, 1 Southpark Circle, suite 306, Charleston, South Carolina, 29407.

Sissenwine, M. P. and P. M. Mace. 1991. ITQs in New Zealand: the era of fixed quota in perpetuity. Fishery Bulletin 90:147-160.

Ulrich, G. F. and G. R. Sedberry. 1990. The wreckfish (Polyprion americanus) in the Southeastern United States. Unpublished Manuscript. Marine Resources Division, SCWMRD, P.O. Box 12559, Charleston, SC 29412. 10pp.

United States Department of Commerce. Fisheries of the United States, 1991. Silver Spring, MD. 
Copyright of Marine Resource Economics is the property of Marine Resources Foundation. The copyright in an individual article may be maintained by the author in certain cases. Content may not be copied or emailed to multiple sites or posted to a listserv without the copyright holder's express written permission. However, users may print, download, or email articles for individual use. 